\title{
Semantic Transformation of Precedent Names in Japanese Songs
}

\author{
Tuyara N. Permyakova ${ }^{1(\varpi)}(\mathbb{D})$ and Anna A. Burakova ${ }^{(D)}$ \\ ${ }^{1}$ North-Eastern Federal University, Yakutsk 677000, Russia \\ ptuiara@mail.ru \\ ${ }^{2}$ Ural Federal University named after the first president of Russia B.N. Yeltsin, \\ Yekaterinburg 620002, Russia \\ anna.a.burakova@gmail.com
}

\begin{abstract}
The paper attempts to identify semantic transformations of precedent names in Japanese songs. Material of practical research is based on the texts of 62 songs modern Japanese electronic band 水曜日のカンパネラ (Suiyoubi no Kanpanera). The choice of this artist is due to the current popularity of the groups among the number of new wave Japanese artists of the 2010s. The authors offer their thematic classification of precedent names in the song's lyrics. In the course of the research, the authors come to the conclusion that not all precedent names remain in the original, primordial meaning, but can have either several meanings or radically change the meaning. The authors see the main reason for semantic transformations in the dynamically changing everyday life of the Japanese and their communication, as well as in the admirers of these songs, which are usually young people and adolescents.
\end{abstract}

Keywords: Japanese linguistic $\cdot$ Japanese songs $\cdot$ Lexical meanings · Precedent names $\cdot$ Semantic transformation

\section{Introduction}

Precedent vocabulary is a stereotypical imaginative and associative complex. It performs a certain cognitive and nominative function, which allows an understanding of some special cultural peculiarities in the language of a certain nation. Among the variety of precedent vocabulary, the precedent names are outlined as the main bearers of the nominative function. The relevance of the present study roots from the need for the study of Japanese precedent names, which in its turn provides an understanding of their major nominative function as well as an understanding of the modern Japanese language and society, the transformation of which is clearly expressed in precedent names as well.

The notion of "precedent" appeared in the Russian linguistic studies rather recently, in the late 90s of the last century, but it quickly entered into use in scientific terminological paradigms. Gudkov was the first one to introduce the term "precedent" into linguistics. Researcher Sulimov continued Gudkov's study of the precedent and it was encouraged by the extensive development of the cognitive linguistics and by 
establishment of the cultural linguistics into an independent field of a scientific research, focused on the revelation of the national mentality and culture through language [1].

Nowadays, the growing interest in foreign national languages and culture, and international relations between nations is one of the most important necessities that appeared according to the time requests. In this regard, much attention is paid to the function of the cognoscibility of the national language and the archive, which conveys national cultural values from generation to generation. Studies of recent years are aimed at determining the original environment of the language that emerged from the national mentality and set the task before linguists to consider the stereotypes embodied in the collective consciousness of the people for many centuries from the point of view of the national and cultural linguistic aspect [2].

The scientific interest in precedence studies was encouraged not only by the need to study the language from the national culture's viewpoint and by ever-changing linguistic cultural community with its sets of information, but also by its further influential capabilities in everyday (conversational), mass media, political, song and many other aspects of discourse [3].

Precedent phenomena has been studied as a part of intertextuality by Western linguistics (intertextuality) [4-6]) and Eastern-European linguistics (precedent phenomena) $[1,7,8])$. Even though there are significant differences in the theoretical approach, these two theories are more complementary than contradictory.

In general linguistics, a precedent is described as a "primary sample phenomenon", presented for evaluation and comparison and its subsequent use as a reference sample to create any secondary phenomenon in the mould of the first [9]. Precedent phenomena being cultural facts are one of the key issues in modern linguistic and cognitive studies [10].

The research by Karaulov showed that precedent names record certain aspects of the national worldview associated with the nomination process [11]. Having addressed to the earlier works in this field, Gudkov elaborated the most comprehensive explication of the phenomenon of precedence. Gudkov defines the precedent as a definite "stereotypical imaginative and associative complex", significant for a particular society and regularly renewed in the speech of the representatives of this society. It is arranged not only by referring to "past" experience or knowledge (becoming a precedent), but also by the way the listener actually acquires a new, unfamiliar, but original, nonstandard representation of an entity, phenomenon, event, fact or thing (creating a precedent) [12].

A precedent name is understood as an individual denomination associated either with a well-known text, which usually is a precedent one itself, or with a precedent situation commonly known to native speakers of a certain language. Precedent names form an important part of the national linguistic worldview; they define a national system of values and disvalues that, to some degree, regulate the behavior of society representatives, uniting "their" people and contrasting them to "others". The precedent name is a cultural linguistic unit with expressive, symbolic and connotative functions, and it is capable of transmitting cultural information [7].

The precedent names are an important part of modern mass communication. Precedent names are not discourse-specific: they are used in texts on various topics (political, cultural, sports, social, everyday life, and advertising) [13]. Presently, one 
can find in most discourses the metaphorical use of a proper noun for a figurative description of a person or a phenomenon that has at least some similarities with a precedent. Such communicative descriptive device helps to draw parallels between personal qualities, attitudes, external factors of the relevant subjects, and also helps to express the attitude and emotional tone of the addressee [14]. However, the status of the precedent name in the receiving culture determines whether any fragment of the information required for a comprehensive interpretation of the message is lacking and needs to be clarified in translation [15].

Therefore, this article studies such relevant issue in linguistics as precedent names. The purpose of this study is to identify the semantic transformations of precedent names in the modern Japanese language.

\section{Materials and Methods}

We have selected the lyrics of a modern Japanese electronic group called 水曜日のカン パネラ (Suiyoubi no Kanpanera, or "Wednesday Campanella" in English) as a reference material for studying the transformation of precedent names in Japanese. The choice of this group is conditioned by its popularity among the new wave of Japanese artists of the 2010s (each music video on the official group channel on Youtube video hosting consistently gains more than 2-3 million views). The most popular song of the group 「桃太郎」(Momotarō) - scored 15,879,453 views.

Unlike other modern Japanese music industry representatives, performing in such popular genres as aidoru-uta, j-pop, dance pop, whose mostly love songs are performed without any special message, the songs of "Wednesday Campanella" describe various historical events, famous personalities and mass pop culture in general.

Methods of research included general scientific methods of observation, description, generalization with the elements of discursive contextual and content analysis of songs' lyrics. The research material was comprised of 62 song lyrics from which 91 units of precedent names. The data was collected in accordance with continuous sampling method from each song's lyrics under study. We identified precedent names by such criteria as connection of the corresponding names with classical works [8], as well as the general knowledge of the corresponding phenomena, or at least their familiarity to most members of the linguistic community (Krasnykh and Gudkov) [16].

The selected material was analyzed to identify global and local precedent names and their classification.

\section{Results}

Upon analyzing the precedent names transformation in the lyrics of Suiyoubi no Campanella, we identified the following names: anthroponyms, toponyms, zoonyms, filmonyms, mythological names, caronyms, theonyms, ergonyms, pragmatonyms and eventfulness. 


\subsection{Anthroponyms}

The study revealed 7 groups of anthroponyms with a total of 46 units. They were classified as follows: 1) precedent names that designate literary works and well-known literature characters (6 units); 2) precedent names denoting world historical figures (10 units); 3) precedent names denoting Japanese historical figures (6 units); 4) precedent names for characters of feature films (6 units); 5) precedent names denoting the media personalities of mass pop culture (6 units), 6) precedent names that designate children's fairy tales (7 units); 7) precedent names for fictional characters of modern Japanese popular mass culture (manga, anime, games, etc.) (5 units).

Precedent names that designate literary works and well-known literature characters consider the following example:

祸 (Nero; Nello) - one of the main characters of the "Nello and Patrasche" novel, written by Maria Louise de la Ramée and published with her pseudonym Ouida in 1872. The novel became very popular in Japan, it was several times cinematized into a feature film, animated film and animated series. As the story tells, Nello had been an orphan since his childhood, he lost his only caregiver in the person of his grandfather and is left alone with his best friend - the Patrasche dog. He met many people and faced various hardships of fate. At the end of the novel Nello and Patrasche tragically died of starvation on Christmas Eve.

The song lyrics, where 祸 (Nero; Nello) is the title, mention certain moments of the novel, which are direct references to the literary source:

5時のサイン 町の匂いコトコトス Go-ji no sairen machi no nioi kotokotosu At 5 o'clock in a quiet holiday city it smells like corn soup

ぼこに行くの?も聞こえないDoko ni iku no? mo kikoenai I won’t ask: "Where will you go?"

独りきりの食卓でこの樹のように永遠に Hitorikiri no shyokutaku de kono ki no yōni eiein ni Sitting alone at the kitchen table forever and ever, like that tree...

Japanese readers and viewers sympathize with the poor but good child, who has continuously been challenged by fate that took his and dog's life in the end. They feel sorry for him, but they understand that Nello went to Paradise. Following the main religions of the Japanese, such as Shintoism and Buddhism, it is believed that his suffering provides happiness in the next life.

Thus, the main character, associating himself with Nello, feels deep loneliness and humbly but fearlessly awaits death at the end.

\subsection{Zoonyms}

Precedent names that designate widespread events in society, that became a part of popular culture. One precedent name found: a song called 「西玉夫」(Nishitamao).

Nishitamao or Tama-chan is the name of a seal that was saved on the shore of Tokyo Bay in 2002. After that it began to swim in public places regularly. First, it sailed on the Tamagawa River, from which it received its nickname. This is mentioned in the song:

手を伸ばせば広がる多摩川が Te wo nobaseba hirogaru Tamagawa ga The Tamagawa River extends, just stretch your arms out 
アザラシをのせ下流へと Azarashi wo nose karyū he to Let's rush down the river together with a seal.

In the song, the main character, along with a seal, sets off on an adventure around the world, meeting a panda and visiting Turkey:

チグリス長江を渡るパンダ南無ダ Chigurisu chyōkō wo wataru panda amida Have mercy on the panda that crosses the Yangtze River

カッパドキアくぐり抜けた先のラクダ墓場 Kappadokia kugurinuketa saki no rakuda bochi Walking in Cappadocia to the Camel Cemetery.

Here, Tama-chan personifies the desire of the main character to travel the world, from which we can conclude that Tama-chan is a guide to the world.

\subsection{Toponyms}

Among the toponyms, two groups were identified: 1) precedent names that designate widely known geographical features (6 units); 2) precedent names that designate certain events by indicating the place where they occurred ( 5 units).

Among the precedent names of the second group, we would like to note the following example:

岡山 県 Okayama-ken, Okayama Prefecture - legend has it that it was precisely in Okayama Prefecture that the events of Momotaro's tale happened at and that a real prototype of a tale's hero lived there. The song「桃太郎」 (Momotarō) narrates that Okayama boasts with the most delicious kibidango - Japanese traditional sweet:

渡されたのは岡山県名物「きびだんご」Watasareta nowa Okayama-ken meibutsu "kibidango" They gave him the famous Okayama kibidango

ただそれだけ Tada sore dake And that's all.

\subsection{Filmonyms}

Precedent names that designate the names of feature films. 7 units in total.

Consider the following example:

ランボー Ranbō; John Rambois the protagonist of the "Rambo: First Blood" film, directed by Ted Kotcheff, based on the like-named novel by David Morrell, released in 1982.

According to the plot of the film, Rambo is a veteran soldier who lives only by war. The song mentions all popular types of firearms: シグザウエル P226 (Shiguzaueru P226; SIG Sauer P226), 狙い定めて PSG1 (Neraisadamete PSG1; Sniper PSG1), etc. All this alludes to the main themes of the film, as war and violence, but Rambo in this case represents a person very motivated on losing weight. The song humorously depicts all the efforts of an office worker, personified by Rambo, who exhausts himself by all the means and trainings to lose weight. For example:

ナッツぎっり確かな満足 Nattsu gisshiri tashikana manzoku Very nutritious nuts

休み時間にメタボを解消 Yasumi jikan ni metabo wo kaishyō I will burn my belly fats during the weekend

ヘンチプレスにヒンズースクワッ Benchipuresu ni hinzū sukuwatto Will do a bench press 
趣味は散歩とホット Shyumi wa sanpo to hotto yoga My hobby is walking and hot yoga

安心 安全 安定第一 Anshin anzen antei daiichi Calmness, safety, sustainability are my priorities

俺の名前はジョンランボーOre no namae wa Jon Ranbō And my name is John Rambo.

In this song John Rambo appears as a typical Japanese office worker who begins to grow fat because of work-related stress. He compares work to battlefield (こさは戦場 Koko wa senjō; here is the battlefield), and losing weight to a battle.

\subsection{Caronyms}

Precedent names that refer to ship names. 1 unit found.

サンタマリア (Santamaria; Santa Maria) is the ship of Christopher Columbus, which he navigated and discovered America. In the song “ダ・ウインチ” (Da Uinchi; Da Vinci) the name of this ship is mentioned as a means of transportation to the mysterious border of knowledge:

サンタマリア 不思議な境界線 思考回路 Santamaria fushigina kyōkaisen shikō kairo Santa Maria, a mysterious borderline, thought pattern.

\subsection{Theonyms}

Precedent names that denote religious personalities and events. 5 units were investigated in total.

For example: $\overline{-}(\mathrm{R} \bar{a} ; \mathrm{Ra})$ is the ancient Egyptian deity of the sun. Ra is mentioned in the song of the same, but the song describes a Japanese everyday dish - curry with rice, namely カレーメシ (karē meshi) an instant food with cooked rice and curry:

CURRYの鮮やかなYELLOWから CURRY no azayakana YELLOW kara From the vivid yellowness of curry

輝くル一太陽神ラ一 Kagayaku rū taiyō kami Rā Ra, The radiant God of Sun

みなぎるピラミッドパワー Minagiru piramiddo pawā Pierces a Pyramid with his power.

These lyrics represent a direct reference to the Kare:meshi packaging: the appearance of the box is yellow, and the shape resembles something of a pyramid. The text also contains expressions in English alluding to food like: So Just Eat It, Golden Rice, Golden Spice. This song most likely is an advertisement for Karē meshi, and Ra is employed in the following sense: this product is the food of gods.

\subsection{Ergonyms}

Ergonyms are names of business associations of people, for example, unions, organizations, institutions, corporations, enterprises, societies, institutions, circles [17]. In the course of this study, 4 units were identified.

The "Sen-no Rikyu" song, dedicated to the tea ceremony master, mentions some of the largest Japanese corporations: Itoen (伊藤園; Itōen) and Nagatanien (永谷園; 
Nagatanien). Itoen is a tea-producing corporation. Nagatanien produces lots of instant Japanese food products.

夢と魔法と茶道の王国オレが目指す地上の楽園 Yume to mahō to sadō no ōkoku ore ga mezasu chijo no rakuen The kingdom of dreams and magic and tea ceremony, the earthly paradise I'm aiming for.

動物園 後楽園 失楽園 伊藤園 永谷園 Dōbutsuen Kōrakuen shitsurakuen Itōen Nagatanien A zoo, Korakuen, Paradise Lost, Itoen, Nagatanien.

\subsection{Mythological Names}

Precedent names that designate mythological creatures. 10 units found.

チュパカブラ Chupakabura; Chupacabra is a character of urban legends who kills animals and sucks their blood. According to another legend, this is a predator, mutated mainly from the canine family. In the eponymous song, Chupacabra represents a medical needle: either the needle used to take a blood test, or the usual antiviral vaccine. The reason for this injection is given in the lyrics:

守りたいこの笑顔と血糖值 Mamoritai kono egao to kettōchi I want to protect their smiling faces and blood sugar levels.

Most likely, based on this line, "Chupacabra" is a vaccine for diabetes that many people suffer from. Probably the injection is called chupacabra because the injection is always associated with blood and veins, not because the main heroine turns into a beast and begins to drink blood like this mythical creature.

\subsection{Pragmatonyms}

Precedent names that denote different types of games present in popular culture. 3 units were identified.

For example, モノポーー (Monoporī; “Monopoly”). Monopoly is a board game in the genre of economic strategy. The aim of the game is to bankrupt other players using one's own starting capital. This game imitates different business activities, so it's very lifelike. In the lyrics Monopoly rather represents life, thus, real districts, places, and sights of Tokyo are randomly and chaotically mentioned.

\subsection{Eventfulness}

Precedent names that refer to events by indicating their date ( 3 units). For example:

江戸 (Edo; Age of Edo) - the historical period of Japan, the reign of the Tokugawa clan from 1603 to 1868 . This precedent name is mentioned in a song called お七 ( $O$-shichi; Seven) refers to one of the famous ukiyo-e paintings: 八百屋お七 (Yaoya $O$-shichi; "Greengrocer Oshichi”), produced in the abovementioned Edo period by Tsukioka Yoshitoshi in 1667, the last artist in this genre. Tsukioka literally on his own managed to bring the art of ukiyo-e to a new level, while Japan was abandoning its past. The picture frames an episode from the Kabuki Theater performance about a greengrocer girl who fell in love with a servant boy in a Buddhist temple. The text describes the picture: 
地震雷 乙女の暴走 Jishin kaminari otome no bōsō A young virgin who escaped from the crash of an earthquake

恋のため息ああ一 Take it 僧 僧, Koi no tameiki aa - Take it sō sō For love's sake, hold on, breathe. Take it monk.

The following is a concrete indication of the time:

人情人情江戸江戸前 Ninjō ninjō Edo Edo mae Human nature, Human nature, Edo, Edo style.

Thus, the heroine of the song, identifying her love as that of Greengrocer Oshichi, thinks that her love is just as tragic as it is in performances about the times of the Edo period.

\section{Discussion}

Having analyzed the examples of the precedent names, we have identified many semantic transformations of precedent names. Moreover, not all precedent names preserve their original unchanged meaning: these can either have several meanings or drastically change the meaning, but saving some recognizable features of the precedent, as Momotaro, for example, who from a hero of a children's fairy tale, a courageous warrior, turned into a modern teenager who is encouraged to change for the best, find ajob and stop wasting time, i.e. to do some kind of "heroic" deed like a fairy tale hero.

These transformations may be caused by the dynamically changing manner of the Japanese life and their mass communication. Since the target audience of this group consists of adolescents and young people, it is clear that the views of different generations may differ from each other, that they can look at the same concept in different ways.

\section{Conclusion}

A study of the lyrics of the Japanese popular musical group 水曜日のカンパネラ Suiyoubi no Kanpanera resulted in 10 thematic groups that distinguish precedent names based on the nominative functionality. The most extensive group of precedent names is anthroponyms that vividly express the Japanese national culture, the smallest are groups of zoonyms and caronyms.

Summarizing the analysis of precedent names of a Japanese music pop-group, we can conclude that the revealed structure of classification of precedent names allows us to argue that precedent names capture certain aspects of the national worldview, and their semantic transformations represent a reflection of the modern Japanese young person who inevitably transforms himself, subsequently his everyday life transforms, and, as a result, his attitude to the surrounding reality changes, which is expressed, primarily, in the modern song lyrics. 


\section{References}

1. Sulimov, V.A.: Kognitivnoye opisaniye yazyka i yego kul'turologicheskaya interpretatsiya: kognitivnyye transformatsii. Filologicheskiye nauki [Sulimov, V.A.: Cognitive description of language and its cultural interpretation: cognitive transformations]. Phil. Sci. 1, 44-47 (2006). (in Russian)

2. Murzinova, A., Tymbolova, A., Yelshibaeva, K., Abdirassilova, G., Kushkimbayeva, A., Mirov, M.: The national and cultural peculiarities of stereotyped precedent names (A case study of the Kazakh, Russian, and English languages). XLinguae Eur. Sci. Lang. J. 11(2), 702-715 (2018)

3. Gudkov, D.B.: Pretsedentnoye imya i problemy pretsedentnosti. Yazyk, soznaniye, kommunikatsiya [Precedent names and studies of precedents. Language, consciousness, communication]. Education, Moscow (1997). (in Russian)

4. Allen, G.: Intertextuality. Routledge, London (2000)

5. Eco, U.: Intertextual irony and levels of reading. In: Eco, U. (ed.) On Literature, pp. 212235. Harcourt, New York (2006)

6. Orr, M.: Intertextuality: Debates and Contexts. Blackwell Publishing Oxford (2003)

7. Krasnykh, V.V.: Etnopsikholingvistika i lingvokul'turologiya: kurs lektsiy [Ethnopsycholinguistics and Linguoculturology: Lecture Course]. Gnozis, Moscow (2002). (in Russian)

8. Karaulov, Y.N.: Rol' pretsedentnykh tekstov v strukture i funktsionirovanii iazykoovoi lichnosti [The role of precedent texts in the structure and functioning of a linguistic personality]. Bull. Orenburg State Univ. 11(186), 65-70 (2015). (in Russian)

9. Golubeva, N.A.: Pretsedent i pretsedentnost v lingvistike [Precedent and precedent in linguistics.]. Vestnik Vyatskogo gosudarstvennogo gumanitarnogo universiteta 3(2), 56-61 (2008). (in Russian)

10. Bolotina, K.E.: Precedent phenomena in Quebecois linguistic world view. Vestnik Rossiiskogo universiteta Druzhby Narodov. Seriya Lingvistika. Russ. J. Linguist. 20(2), 61-76 (2016). (in Russian)

11. Karaulov, Y.: Russkiy yazyk i yazykovaya lichnost' [Russian Language and Language Personality]. Nauka, Moscow (1987). (in Russian)

12. Gudkov, D.B.: Pretsedentnyye fenomeny v tekstakh politicheskogo diskursa. Yazyk SMI kak ob"yekt mezhdistsiplinarnogo issledovaniya [Precedent Phenomena in the Texts of Political Discourse. Media Language as an Object of Interdisciplinary Research]. Moscow State University, Moscow (2003). (in Russian)

13. Dulebova, I., Kryukova, L.: Precedent names of the Russian culture and history in modern Slovak media. Tomsk State Univ. J. 425, 19-25 (2017). (in Russian)

14. Yermolovich, D.I.: Imena sobstvennyye na styke yazykov i kul'tur [Proper Names at the Junction of Languages and Cultures]. R. Valent, Moscow (2001). (in Russian)

15. Tashchenko, G.: Translation Today: National Identity in Focus (Studies in Linguistics, Anglophone Literatures and Cultures). Peter Lang Publishing, Bern (2019)

16. Krasnykh, V.V.: Kognitivnaia baza i pretsedentnye fenomeny $\mathrm{v}$ sisteme drugikh edinits $\mathrm{i}$ kommunikatsii [Cognitive base and precedents are not phenomena in the system of other units and in communication]. Vestnik MGU. Filologiia 3, 62-85 (1997). (in Russian)

17. Gudkov, D.B.: Pretsedentnyye imena i paradigma sotsial'nogo povedeniya. Lingvostilisticheskiye i lingvodidakticheskiye problemy kommunikatsii [Precedent names and the paradigm of social behavior. Linguo-stylistic and linguodidactic problems of communication]. Education, Moscow (1996). (in Russian) 